\title{
Metropolitan Regions, Planning and Governance
}

edited by Karsten Zimmermann, Daniel Galland, John Harrison, Springer

Nature Switzerland, Cham, 2020, 270 pages, ISBN 978-3-030-25632-9.

\section{Peter Ache}

To cite this article: Peter Ache (2020) Metropolitan Regions, Planning and Governance, European Planning Studies, 28:8, 1691-1692, DOI: 10.1080/09654313.2020.1759493

To link to this article: https://doi.org/10.1080/09654313.2020.1759493

曲 Published online: 04 May 2020.

Submit your article to this journal 주

Џ Article views: 46

Q View related articles $\widetilde{ }$

View Crossmark data \lceil 


\section{BOOK REVIEW}

\section{Metropolitan Regions, Planning and Governance, edited by Karsten Zimmermann, Daniel Galland, John Harrison, Springer Nature Switzerland, Cham, 2020, 270 pages, ISBN 978-3-030-25632-9.}

We are constantly reminded today that ideas precede and shape the appearance of new "facts". The ancient philosopher of Alexandria, Philo Judaeus, taught that there is a city of ideas that predetermines and commands the material world in which we live, and this greater city of ideas Philo called Megalopolis. (Gottmann, 1961, p. 772)

When reading Metropolitan Regions, Planning and Governance edited by Zimmermann, Galland and Harrison, I was reminded of the above quote from Jean Gottmann. To start with at the outset, the essence of this book in my view might actually be caught as discussing the 'idea' of metropolitan regions that presides all, the empirical setting, the conceptual and theoretical approaches, and finally and most importantly, the strategic dimensions. Though, Gottmann spoke about the megalopolis (another 'idea') of the US American East Coast. And, as I learned from Feiertag, Harrison and Fedeli, who co-authored Chapter 9 in the book, Gottmann was not the first to talk about the megalopolis, but instead, Patrick Geddes in 'Cities in Evolution' from 1915. Obviously, this publication is neither the first attempt to 'fence in' the metropolitan region, as can be seen from the rich set of sources used in writing the individual contributions.

This book is the result of an international working group established in 2016 (running until 2019) by the Academy for Spatial Research and Planning (ARL), Hanover, Germany. The remit for this group of academics, and partly practitioners, from eight different European countries was to present in a consistent way the existing academic knowledge and discourses on the planning and the governance of metropolitan regions in Europe. The academic output of this working group is now presented in this book.

What you get is what you see from the book title, a comprehensive approach to define the object of desire, the metropolitan region and its forms, using a number of examples from across Europe. Throughout fourteen chapters and over 270 pages the authoring team addresses many relevant issues, based on the most recent discourses in planning, geography, sociology, and policy sciences, to name the academic fields represented by contributors. The book is bound together by a conceptual idea, a framework consisting of thematic-temporal-phronetic dimensions (with reference to Flyvbjerg, 2001, 2004); phronetic alluding to "elucidating where we are, in whose interest this is, where we want to go, and what is desirable according to different sets of values and interests" (Chapter 1 by Galland and Harrsion, p. 8). Each section and each chapter is supposed to build on that framework, a blueprint which is not always achieved in its ideal form. The sections of the book follow four thematic dimensions: institutions and institutional shifts; policies and ideas; spatial imaginaries; and, planning styles. The individual chapters are sometimes successive story lines by the same authors (Chapters 8 to 10, authored in varying combinations by Harrison, Fedeli and Feiertag, or similarly, Chapters 11 to 13, authored by Galland, Tewdwr-Jones and Șahin), with themes being presented as variations of a central topic, like metropolitan region 'imaginaries' or 'planning'.

With respect to metropolitan region 'planning', the authors in charge develop a broad perspective. Planning is presented in many variants throughout the book, not least by way of analysing strategic approaches defined for metropolitan regions like e.g. Hamburg, Brussels, or Milan. However, the 'planning styles' part of the publication - which at the same time attempts 
to look into the future - provides three central propositions to it: "We point at the required 'agility' of metropolitan planning to 'break through' proactive and participatory long-term visioning exercises, to 'break up' into co-visioning and co-produced forms, and to 'break out' into projects, events and interventions that seem to stretch beyond the limits and parameters of single fixed plans. Our intention in the final chapter is to question the styles through which metropolitan regions could perform in what we label a 'post-policy era' in metropolitan planning." (Chapter 11 by Galland and Tewdwr-Jones, p. 197). The element of agility is found in "series of short-term, project-focused and highly agile planning processes [...] legitimized for specific needs and contexts, but which are capable of being disbanded just as easily" (Tewdwr-Jones and Galland, Chapter 13, p. 234). The "post-policy era" can be seen amongst other elements in "new modes of operating, different types of partnerships, new testing beds to trial projects, services and ideas, and legitimacy for initiators that might be outside traditional institutions of power." (Galland, Harrison and Tewdwr-Jones, Chapter 14, p. 248). And the promised question reads: "When all this has been said and done, we aim to have convinced you, the reader, never to assume that metropolitan regions are the (only) answer. Often it can be easy to assume they are. But if planning and governing metropolitan regions are to continue providing answers to twenty-first-century problems, perhaps the starting point should be to ask: if metropolitan regions are [emphasis added by authors] the answer, what question is being asked?" (Galland, Harrison and Tewdwr-Jones, Chapter 14 , p. 255).

The book, in one way, can be seen as a reference book that provides good overviews of the relevant literature and the historic development of the debate on metropolitan regions; also, it looks into existing examples with a high level of detail. On the other hand, as epitomized by the last quotes above, the book leaves the reader actually puzzled. The metropolitan region is certainly a construct that satisfies many desires, this much becomes very clear in many chapters. The big pictures painted by diverse institutions and actors in strategies for metropolitan regions often cloud our perspectives on concrete spatial or urban utopias (Bloch) for the twenty-first century. It would have been particularly interesting to break this up and to read the more specific questions to be asked, and subsequently, to read the answers. Just following the well-chosen reference to "phronetic planning research" (p. 8): what are the consequences and to whom and how could power relations be changed to work in more progressive ways?

Peter Ache Institute of Management Research, Radboud University, Nijmegen Q p.ache@fm.ru.nl

(C) 2020 Peter Ache https://doi.org/10.1080/09654313.2020.1759493

Check for updates

\section{Works cited}

Flyvbjerg, B. (2001). Making social science matter: Why social inquiry fails and how it can succeed again. Cambridge University Press.

Flyvbjerg, B. (2004). Phrotentic planning research: Theoretical and methodological reflections. Planning Theory \& Practice, 5(3), 283-306.

Geddes, P. (1915). Cities in evolution. An introduction to the town planning movement and to the study of civics. Williams.

Gottmann, J. (1961). Megalopolis. The urbanized north eastern seaboard of the United States. MIT Press. 